\title{
Approbation of Results Obtained During Interview: Research of Possibilities for Exercising the Rights of Political Oppositions in Lithuanian Self-Government
}

\author{
Ph.D. candidate Karolis Kaklys \\ ORCID: 0000-0002-7020-5314 \\ Kazimieras Simonavicius University, Lithuania \\ karolis.kaklys@ksu.lt
}

\begin{abstract}
Analysing the problematic aspects of the legal regulation of local self-government of the Republic of Lithuania related to the realisation of the rights provided for the minority (opposition) of the municipal council in the Law on Local Self-Government and other legal acts, the following empirical research was performed. During the research, the method of interviews was used in order to identify, as precisely as possible, the problems of the realisation of the rights of political minorities (opposition) in the whole Lithuanian municipality. It is the interview method that was chosen to ensure the interaction between the researcher and the respondent, which enables to obtain the widest and deepest possible information in identifying practical problems and also allows to collect the detailed data needed to solve the identified problems. The interview focused on the target group of respondents from many different Lithuanian municipalities who are fully acquainted with the practical aspects of the realisation of the minority rights of the council. All respondents are current or former opposition members of municipal councils. With the aim of maximising practical benefits, as many as thirty respondents were interviewed in this research.
\end{abstract}

Keywords: local self-government, political minority's rights, opposition.

\section{Introduction}

After direct mayoral elections held on March 1, 2015 in as many as sixteen Lithuanian municipalities - Birštonas municipality, Druskininkai municipality: Ignalina district, Jonava district, Kaunas district, Lazdijai district, Marijampolè municipality, 
Karolis Kaklys. Approbation of Results Obtained During Interview: Research of

Possibilities for Exercising the Rights of Political Oppositions in Lithuanian Self-Government

Neringa municipality, Pagègiai municipality, Palanga municipality, Pasvalys district, Rietavas municipality, Šakiai municipality, Šalčininkai municipality, Vilkaviškis district, Vilnius district (Central Electoral Commission of the Republic of Lithuania, 2015), one political party or movement won an absolute majority in the elections. After the March 3, 2019 municipal elections, the number of "one-party" municipalities increased to seventeen (Central Electoral Commission of the Republic of Lithuania, 2019), which further highlighted the importance of ensuring the minority (opposition) rights of the council in the municipalities. Thus, it could be further noted that during the 2019 direct mayoral elections, as many as 39 mayors (out of 60) were re-elected for the next term.

Separation of authorities is one of the most important constitutional principles of a democratic state, which influences organisation of state authority, its functioning, and guarantees human rights and freedoms. The principle of separation of powers can be divided into two interrelated parts: 1) interaction of authorities - usually associated with relations between individual authorities, which are understood as cooperation between authorities, coordination of actions, functioning of the system of "checks and balances" ensuring control and balance between governments; 2 ) separation of authorities - it is not only the division of authorities into branches of state authority, but also determination of their own internal formation procedure, legal status, powers and competencies, and assurance of their independence (Jarašiūnas, 2001).

J. Madison, one of the main founders of the doctrine of the division of authorities, also held the position that constitutional framework defining the powers of each individual government was insufficient. He argued (Madison, 1999) that a mechanism was needed to guarantee self-regulatory control of the branches of government. "J. Madison's aim was to protect freedom and interests of the minority by creating a system in which the central authorities remain independent but at the same time control and counterbalance each other. Based on the experience in the states, J. Madison saw the greatest threat (to democracy) in the legislature." (Griškevič, 2008).

Although in science the system of levers and counterweights, usually associated with management of the state rather than municipalities and the institutional structure (Novikovas, 2005), of their government differs substantially, essential principles between municipal councils and the Seimas of the Republic of Lithuania, as collegial authorities in which political decisions (legal acts) are made, are very similar in terms of making decisions themselves. Therefore, a certain analogy between the municipal council and the Seimas of the Republic of Lithuania can be seen, in particular on separation of authorities, with regard to the procedure for their internal formation, determination of authorities and competences between the majority and the minority. Thus, when emphasising the importance of the political opposition of municipalities, the analogy of the Seimas of the Republic of Lithuania can be partially relied upon.

The Constitutional Court of the Republic of Lithuania has noted that the Constitution of the Republic of Lithuania presupposes protection of the parliamentary minority, the minimum requirements (Constitutional Court of the Republic 
of Lithuania, 1993) for the protection of the Seimas opposition, and that the recognition of the parliamentary opposition is a necessary element of a pluralistic democracy (Constitutional Court of the Republic of Lithuania 2001). The Statute of the Seimas may establish guarantees for activities of the opposition - a certain number of seats and positions in committees, status of the leader of the opposition, initiation of agendas and commissions, and so on. A systematic assessment of the provisions of the Law on Local Self-Government of the Republic of Lithuania shows that the obligation to form a Control Committee, Anti-Corruption and Ethics Commissions in each municipality to which the opposition is delegated by the opposition is one of the ways envisaged by the legislator to ensure pluralist democracy.

Presence of the opposition in every municipal council is not only a normative phenomenon but also a necessary expression of democracy. In essence, the opposition has two main functions. First, it prevents establishment of one party and curbs arbitrariness of authority, helping to maintain the constitutional model of authority. Second, because political decisions are not perfect, the opposition points to the mistakes and shortcomings of the government. The opposition is a means of limiting power and fostering social peace.

Although there is no precise, universally accepted definition of democracy (Kekic, 2007), a democratic form of government means that all citizens have the right to participate in the governance of a country and is fundamentally different from a form of government in which such a right belongs to one class, exclusive group or autocrat. Even before the introduction of direct mayoral elections in Lithuania, Lithuanian scientists (Urmonas \& Novikovas, 2011), noted that "[o]ne of the most important foundations of a democratic society is a multi-party system" and suggested that "the election of direct mayors may lead to the development of oligarchic tendencies".

The aim of this empirical research is to identify the main problems of the realisation of the rights of political minorities (opposition) in Lithuanian self-government with the help of respondents from different Lithuanian cities.

The article is divided into three parts. The first part presents the methodological substantiation of the research, the formulation of the interview questions, the strategy and the course. The second part summarises the results, and the third part presents conclusions.

\section{Strategy and Methodology of Survey of Opposition Representatives of Different Lithuanian Municipal Councils}

The specifics of the research object determined the choice of qualitative research methods, because the solution of the problem formulated in the article requires analysis of many variables, and some of them are difficult to identify by theoretical means alone. Qualitative methodology does not constrain the researcher with standardised procedures and allows to gather detailed information about the object of research necessary for 
Karolis Kaklys. Approbation of Results Obtained During Interview: Research of

Possibilities for Exercising the Rights of Political Oppositions in Lithuanian Self-Government

solving the problem. Abundance of data does not necessarily mean quality of information. In terms of interactions, quantitatively based individual studies can provide useful insights based on analysis of pre-existing relationships. However, the interaction itself is an ever-changing process. The qualitative approach is based on more flexible methods and provides better opportunities to predict the causal links between different processes and the perspectives of an individual's behavior. The results of quantitative research only show the existence of problems. Quantitative research can help with hypothesis testing and statistical generalisation (Tummers, 2011). It can be stated that qualitative analysis would allow to fully understand the problems raised in the research paper - for which data collected using quantitative methods signal - the causal links between the underlying processes and factors. In order to ensure that research does not become only a tool for data collection, but actually serves to improve municipal management processes, it is appropriate to combine elements of quantitative methodology and qualitative approach. The researcher using the qualitative research approach does not seek to gather as many facts as possible, the qualitative methodology allows to focus on a deeper analysis of the collected information.

In order to achieve practical benefits and novelty of the work, the possibilities of the qualitative approach to generate conclusions and recommendations that would be relevant and useful in decision-making should be emphasised. Therefore, supplementing the ongoing research with elements of a qualitative approach is particularly relevant.

Thus, in the qualitative research it was decided to additionally use the interview method. This method is used to gather comprehensive understanding of the research object. To obtain important data based on the knowledge of competent persons who are fully acquainted with the practical aspects of the realisation of the minority rights of the council in their activities. The interview method was chosen to ensure the interaction of the researcher and the informant, which enables to obtain wider and deeper information by detailing and asking additional questions, to gather information useful for the research not only from theoretical knowledge provided by experts and scientists.

Most of the data required for the research is obtained by linguistically assessing the information provided directly in the statements (surveys) of the representatives of the municipal opposition. However, in order to maximise the reliability of the data obtained from the research, it is important to take into account observations made by researchers that public administration research is too little focused on issues related to the culture of public sector organisations and the internal climate, and even applied research that provides recommendations for solving real problems rarely analyses how the internal culture and work atmosphere of a municipality have a significant impact on the implementation of public policy and the activities of organisations themselves (McNabb, 2002). Therefore, when formulating the questionnaire and conducting the interview, it is necessary to pay attention to the fact that when interviewing respondents in a structured way, without direct contact and researcher intervention (e.g. questionnaire 
Karolis Kaklys. Approbation of Results Obtained During Interview: Research of

Possibilities for Exercising the Rights of Political Oppositions in Lithuanian Self-Government

method), an important part of the aspects relevant to the research would go unnoticed. For example, adjustment of informants' thought process, attentive listening, voice intonation, and nonverbal behavior during interviews. Therefore, the interview survey method provides an opportunity to assess beginnings of understanding of the phenomena that shape the management culture.

Thus, the researcher cannot know some details in other ways than by asking the respondents questions, which helps with the better assessment of the mentioned phenomena and management culture. The data obtained from the interviews can be divided into two groups (Gomm, 2004): 1) things that can be considered as facts, and 2) things that are inherently unconfirmable because they involve matters of self-knowledge. For example, the informant may provide specific examples and identify situations not described elsewhere due to statutory rules, and these will be indisputable facts that reflect reality. However, statements about the lack of legal regulation and identification of its shortcomings and directions for improvement are already partly decisive in terms of internal beliefs and possible practical experience. This may lead to objections to the credibility of the interviewee's statements, as the informant is chosen as an authoritative source of information; however, their opinion cannot be accepted as a priori correct. Deciding which information obtained during the interviews can be considered relevant data and evidence for the research is a crucial task. It is difficult for the researcher to prove that he or she does not invent the data and does not misrepresent the informant's opinion, so any research results must be critically evaluated, the validity of which becomes a closed circle.

Thus, the choice of technique to transform an interview into data should focus on epistemological issues and, in particular, on what should be considered as data from the researcher's perspective (Mason, 2002), that is, it is important for what purpose and for what information the interview method is used, as well as how it is expected to logically integrate the obtained data into the overall set of data analysed in the research and consistent interpretations of the studied phenomena. Thus, the main problem of scientific methodology can be identified as the organisation of an efficient and effective process of scientific cognition (Gudelis, 2007).

In this research, informants are interviewed in order to gather not only the knowledge about the object of the research obtained with the help of theoretical methods and document analysis, but also data that cannot be effectively collected in other ways. The object of the research can be conceptualised from various positions; therefore, it is crucial to approach the research questions more broadly from the aspects relevant to practical activities. Taking into account that there are 60 separate territorial administrative units (municipalities) in Lithuania; therefore, the application of the survey (interview) method will help to reveal the object of research more and will ensure the reliability of the data in interaction with the observation method applied by the author. In this context, it should be noted that the author of this research himself has been a member of the opposition of the municipal council for more than ten years. 
Karolis Kaklys. Approbation of Results Obtained During Interview: Research of

Possibilities for Exercising the Rights of Political Oppositions in Lithuanian Self-Government

In applying the above methods and in formulating the research strategy, the different research methods should be combined in the light of (Mason, 2002, 34):

1) technical integration: data collected by different methods or from different sources must be identical or complementary in technical or procedural terms so that they can be easily combined and grouped, or in some way comparable;

2) ontological integration: data must be ontologically compatible. In other words, they must be based on uniform, consistent or comparable assumptions about social existence and phenomena;

3) integration at the cognitive and evidence substantiation levels: includes questions of whether different methods and data derive from the same epistemological provisions or are at least epistemologically compatible, that is, must be based on the same or harmonised assumptions about the generation of knowledge and the validity of the evidence;

4) integration at the level ofexplanation: also includes epistemological issues, but focuses on constructing explanations and generalisations. The data obtained using different methods should be useful for comprehensible and convincing reasoning to help solve difficult research questions.

A characteristic feature of the exploratory interview is that all the information is obtained orally. In that, it is fundamentally different from a questionnaire survey. There are more differences. For example, interviews provide wider opportunities to get to know the subject in more depth, whereas in a questionnaire survey such opportunities are very limited. On the other hand, interviews are less likely to cover more respondents than a questionnaire.

The purpose of the exploratory interview method, according to L. Cohen and L. Manion, can be used in three ways (Cohen \& Manion, 1989):

1) it can be used as a direct and basic means of obtaining the necessary information; for example, to find out what the respondent thinks (attitudes), what the person knows (knowledge information), what he likes and dislikes (values);

2) as a tool to test a hypothesis; for example, to identify or refine the relationships between variables and a study event;

3) can be used in conjunction with other research methods both to gather information and to evaluate other methods such as a questionnaire.

Four types of interviews are possible in research practice (Kardelis, 2017):

1) structured (questions and the whole procedure are planned in advance and little is changed during the interview; in this case the situation is defined);

2) unstructured (without a detailed plan, questioning in free form; the situation is open and able to change);

3) non-imposed (the interviewer does not try to maintain the intended line of conversation, but gives in to the course of the interview imposed by the respondent); 
Karolis Kaklys. Approbation of Results Obtained During Interview: Research of

Possibilities for Exercising the Rights of Political Oppositions in Lithuanian Self-Government

4) purposeful (the interviewer pays special attention to the respondent's subjective answers about the situation known to him, which he became acquainted with before the interview; from the answers received, the researcher can decide whether his hypothesis has been confirmed or not). This type of interview was chosen for the survey of the representatives of the opposition of the municipal councils.

When researching the possibilities of the realisation of the opposition rights of municipal councils (practical implementation) - interviewing selected local politicians is potentially useful due to the fact that the features that shape the practical content of the research phenomenon may differ radically from theoretically (both in legal regulation and research) defined assumptions and conclusions. Additionally, proper implementation of the rights of municipal opposition is one of the most important standards of good governance; therefore, in order to objectively understand the established traditions of local government governance - the findings of the research need to be based not only on subjective beliefs, but also to integrate municipal opposition. However, this does not mean that the views of the interviewees must be considered unequivocally correct. Informants are interviewed in order to deepen the analysis, covering more questions, the interpretation of which would enable objective assumptions to be confirmed or refuted objectively.

Therefore, the interview method aims to obtain data that:

1) reflect the practical possibilities for the realisation of the rights provided by law to the municipal opposition at the national level;

2) would allow to identify, evaluate and understand specific problems of practical realisation of the rights of the local opposition in separate Lithuanian municipalities;

3) would play a role in critically evaluating data collected by other methods;

4) would allow to decide on the prevailing views among the respondents on the importance of the analysed issue and the scale of relevance;

5) views would be reasoned, based on examples and reasonably explained;

6) would be useful (logically integrated) for a common objective understanding of the phenomena under research.

The survey of municipal opposition representatives can be named as a control method for scientifically objective knowledge of the researched phenomena. It can be stated that the interview method is used to refine and verify the data obtained by observation, document analysis and other methods.

It is advisable for the interviewer to try to take such a position as if he or she knew nothing about the situation under investigation, as if the most important and obvious aspects of the phenomenon under investigation are better understood (Babbie, 2007). However, such a proposal is more appropriate to accept when analysing data already collected and, of course, to avoid overwhelming the opinion of informants, without affecting the content of their statements. 
K. Kardelis, the author of the textbook of scientific methodology, claims that the interview is one of the effective methods of qualitative research, which guarantees greater reliability than the questionnaire method or other survey methods, as the interview provides wider opportunities to get to know the subject in more depth, whereas in a questionnaire survey such opportunities are very limited (Kardelis, 2002). During the interview, the researcher should be active enough to direct the conversation towards the information of interest. Therefore, in this case, the expert survey is conducted using the semi-structured interview method. The questions aim to reveal the views, assessments and reasoning of the opposition representatives of different municipalities not only about the object of research, but also about other phenomena, factors and assumptions raised in the theoretical part. Semi-structured interviews allow interviewees to express their views better than structured interviews and simultaneously provides better comparability of responses than free-form interviews (May, 2001). One of the main advantages of semi-structured interviews is the possibility to change the sequence of questions and refine the questions depending on the course of the interviews (Bailey, 2007).

The interview questions (see Table 1) are guidelines that ensure the volume of data in the expert's statements that is adequate for the research.

Table 1. Preliminary interview questions

1. The questions are intended to assess the attitude of the informants to the main goals of the political opposition of the selfgovernment, practical problems, as well as to determine the need to improve and develop the legal framework

1.1. What are the main goals and functions of theopposition activities of the municipal council?

1.2. What are the most significant legal acts that you could identify in the activities of the municipal council (and the opposition)? (question in order to assess the respondent's legal perception)

1.3. How do you assess the possibilities of the municipal council opposition to influence the decision-making process?

1.4. In your opinion, what are the main obstacles to the realisation of the opposition rights of the council?Are there no obstacles?

1.5. In which areas are there the most problems in implementing the activities of the municipal council opposition?

1.6. Control-additional questions.
2. Questions showing the informants' attitudes towards possible solutions to the problems identified during the interviews by improving the legal framework

2.1. How do you assess the quality of the current legal environment in the context of local government?

2.2. What are the key factors to be considered in order to improve the legal framework in the context of ensuring the minority rights of the council?

2.3. What specifically could you offer in order to achieve better legal regulation in the context of the realisation of the opposition rights of the municipal council?

2.4. Control-additional questions. Discussion. 
Karolis Kaklys. Approbation of Results Obtained During Interview: Research of

Possibilities for Exercising the Rights of Political Oppositions in Lithuanian Self-Government

The information obtained from the interviews with the experts is used both as independent data and as a means to ensure the reliability, relevance and validity of the conclusions obtained from the analysis of the documents. Expert evaluations influence the researcher's perception; therefore, they help to interpret the data better, to see the object of the research more widely, and the integration of information gathered in different ways and from different sources ensures that the principles of objectivity are respected in the process of scientific knowledge.

\section{Summary of Data and Results Obtained Through Interviews (Results)}

This interview research was conducted in collaboration with the Association of Local Authorities in Lithuania (ALAL) who, with the help of their database, helped to distribute the invitations to the target group of respondents, which greatly helped to increase the scope of the survey and to obtain more reliable data.

Thirty respondents from different Lithuanian municipalities participated in the research, and in particular: Vilnius city municipalities, Kaunas city municipalities, Klaipėda city municipalities, Šiauliai city municipalities, Panevéžys city municipalities, Neringa municipalities, Druskininkai municipalities, Trakai district municipalities, Širvintos district municipalities, Varena district municipalities, Lazdijai district municipalities, Šakiai district municipalities, Molètai district municipalities, Utena district municipalities, Kèdainiai district municipalities, Rokiškis district municipalities, Elektrènai municipalities, Kazlụ Rūda municipalities, Kaunas district municipalities, Skuodas district municipalities, Kelmé district municipalities, Kaišiadorys district municipalities, Raseiniai district municipalities, Anykščiai district municipalities.

It should be noted that all respondents are current or former members of municipal councils, chairmen of municipal control committees, ethics or anti-corruption commissions; therefore, they are well acquainted with the topicalities of the researched issues in their practical activities. Among the interviewed respondents, a number of current or former members of the Seimas of the Republic of Lithuania, as well as prominent scientists can also be found.

According to the data received from the respondents during the research, the (results) problems of the realisation of the rights of political minorities (oppositions) in the municipal councils of the Republic of Lithuania could be divided into three separate groups according to their nature (see Table 2). 
Karolis Kaklys. Approbation of Results Obtained During Interview: Research of

Possibilities for Exercising the Rights of Political Oppositions in Lithuanian Self-Government

Table 2. Problems of realisation of the rights of political minorities of municipal councils of the Republic of Lithuania

\begin{tabular}{|c|c|c|}
\hline $\begin{array}{l}\text { 1. According to technical } \\
\text { possibilities }\end{array}$ & $\begin{array}{l}\text { 2. According to the management } \\
\text { culture-established traditions }\end{array}$ & $\begin{array}{l}\text { 3. According to } \\
\text { the legal and political } \\
\text { environment }\end{array}$ \\
\hline $\begin{array}{l}\text { 1.1. Failure to provide information } \\
\text { to members of opposition of } \\
\text { the council. } \\
\text { 1.2. Artificial barriers are created } \\
\text { for members of the council's } \\
\text { opposition to make proposals. } \\
\text { 1.3. Municipal administration } \\
\text { exclusively represents } \\
\text { the interests of the majority } \\
\text { of the municipality and } \\
\text { the mayor. Acts exclusively } \\
\text { biasedly and ignores members } \\
\text { of the opposition. } \\
\text { 1.4. Municipal administration } \\
\text { does not adequately serve } \\
\text { the chairmen of the Control } \\
\text { Committee and the Ethics-Anti- } \\
\text { Corruption Commissions in } \\
\text { opposition positions. } \\
\text { 1.5. Municipal public resources are } \\
\text { often used to satisfy the majority } \\
\text { of group political interests. } \\
\text { 1.6. Opposition members of } \\
\text { the municipal council are } \\
\text { technically prevented from } \\
\text { participating in discussions } \\
\text { during council meetings and } \\
\text { are sometimes not allowed to } \\
\text { speak at all. }\end{array}$ & $\begin{array}{l}\text { 2.1. In some municipalities, there } \\
\text { is humiliation and belittling } \\
\text { of members of the opposition } \\
\text { in the eyes of the public. } \\
\text { The media is often used for } \\
\text { this purpose. } \\
\text { 2.2. There are cases where a } \\
\text { local political majority of } \\
\text { its members form a fake } \\
\text { opposition with the aim of } \\
\text { circumventing the Local } \\
\text { Self-Government Act } \\
\text { and appropriating posts } \\
\text { guaranteed to the opposition. } \\
\text { 2.3. Division into own people } \\
\text { and enemies. With the ruling } \\
\text { majority not changing over } \\
\text { time, there are a number of } \\
\text { cases where members of } \\
\text { the opposition are persecuted } \\
\text { for their political views. } \\
\text { For example, obstacles to } \\
\text { employment in municipal } \\
\text { institutions or companies are } \\
\text { created. This is especially true } \\
\text { for smaller municipalities, } \\
\text { where the municipalities } \\
\text { themselves are the largest } \\
\text { employers. }\end{array}$ & $\begin{array}{l}\text { 3.1. Quality of } \\
\text { administrative } \\
\text { supervision is } \\
\text { extremely poor, leading } \\
\text { to frequent breaches } \\
\text { of the hierarchy of } \\
\text { legislation. } \\
\text { 3.2. Perforated and } \\
\text { insufficient legal } \\
\text { regulation in } \\
\text { appointing members } \\
\text { of the opposition to } \\
\text { positions guaranteed } \\
\text { by law. } \\
\text { 3.3. By the provisions } \\
\text { of the regulation } \\
\text { of the activities of } \\
\text { the municipal council, } \\
\text { opposition rights are } \\
\text { often unduly restricted. } \\
\text { 3.4. The problem of media } \\
\text { independence - it } \\
\text { is very common for } \\
\text { local media to be } \\
\text { publicly funded and to } \\
\text { represent exclusively } \\
\text { the group political } \\
\text { interests of local } \\
\text { government. }\end{array}$ \\
\hline
\end{tabular}

\section{Conslusions}

1. Since there are sixty separate territorial administrative units (municipalities) in the Republic of Lithuania, in which there are different demographic and political situations, different regulations of municipal councils, composition of municipal councils, different management traditions are formed in them. In the absence of a sufficient definition of political minority rights of municipal councils, which ensure the possibilities of opposition activities, the medium develops into autocratic management tendencies. The poor control of decisions taken by municipal councils and administrative actions as well 
Karolis Kaklys. Approbation of Results Obtained During Interview: Research of

Possibilities for Exercising the Rights of Political Oppositions in Lithuanian Self-Government

as a flawed legislative framework make it possible to form situations in which the democratic values and the protection of individual rights and freedoms are threatened.

2. As the Government of Lithuania itself is a political entity in which political parties play a major role, there is a clear risk that decisions relating to administrative control in individual municipalities can be (and in some municipalities are) taken selectively, not through legitimate arguments, but through political agreements, it is, therefore ,necessary to depoliticise the procedure for appointing Lithuanian Government representatives to address the current problem.

3. Clearer legal regulation of the exercise of political minority rights and the establishment of a counterweight mechanism between municipal political majority and minority in national law is becoming increasingly relevant and necessary to maintain a democratic model of governance.

Existing issues need to be addressed by eliminating the need for majority approval of delegated representatives of council member groups or factions to the control committee, leaving it to them to decide which member is best suited to fill statutory positions on the control committee (as well as with ethics and anti-corruption commissions).

\section{Bibliography}

\section{Court practice}

1. Constitutional Court of the Republic of Lithuania 1993 November 26 and 2001 January 25 resolutions. https://www.lrkt.lt/lt/teismo-aktai/paieska/135/ta477/content.

2. Constitutional Court of the Republic of Lithuania 2001 January 25 ruling. https://www.lrkt.lt/ lt/teismo-aktai/paieska/135/ta315/content.

\section{Articles in academic journals}

3. Griškevič, L. (2008). Valdžiu padalijimo teorija pagal J. Madisona (Eng. Theory of separation of powers according to J. Madison). Teise, 66(2). https://epublications.vu.lt/object/elaba:59633164/.

4. Novikovas, A. (2005). Vietos savivaldos esmé ir socialine paskirtis visuomeneje (Eng. The essence of local self-government and its social purpose in society). Jurisprudencija, 77(69). https://ojs. mruni.eu/ojs/jurisprudence/article/view/2951.

5. Tummers, L. (2011). Explaining the willingness of public professionals to implement new policies: a policy alienation framework. International Review of Administrative Sciences, 77(3), 557. https:// doi.org/10.1177/0020852311407364.

6. Urmonas, A., Novikovas, A. (2011). Europos vietos savivaldos chartijoje ịtvirtintu principu igyvendinimo vietos savivaldoje ir inkorporavimo nacionalineje teisés sistemoje ypatumai (Eng. The peculiarities of the implementation and incorporation of the principles of European Charter of Local Self-Government in Lithuanian local government and national legal systems). Jurisprudencija, 18(3). https://ojs.mruni.eu/ojs/jurisprudence/article/view/589.

\section{Literature}

7. Babbie, E. R. (2007). The Practice of Social Reseach (11 ${ }^{\text {th }}$ ed.). Belmont, CA: Thomson Wadsworth, p.309. 
Karolis Kaklys. Approbation of Results Obtained During Interview: Research of

Possibilities for Exercising the Rights of Political Oppositions in Lithuanian Self-Government

8. Bailey, C. A. (2007). A Guide to qualitative field research ( $2^{\text {nd }}$ ed.). Thousand Oaks (Calif.): Sage Publications, p 100.

9. Cohen, L., Manion L. (1989). Research methods in education. (3 ${ }^{\text {rd }}$ edition), London: Routledge.

10. Gomm, R. (2004). Social research methodology: a critical introduction. Basingstoke, New York: Palgrave Macmillan, p.185.

11. Gudelis, D. (2007). Savivaldybiu veiklos matavimo modeliai ir ju igyvendinimo galimybès Lietuvoje: daktaro disertacija. (Eng. Municipal activity measurement models and their implementation possibilities in Lithuania: doctoral dissertation). Vilnius: Mykolo Romerio universitetas, p.106. https://www.lituanistika.lt/content/10767.

12. Jarašiūnas, E. (2001). Valdžiu padalijimas - demokratinès valstybès valdžios organizacijos ir veiklos principas. Lietuvos konstitucine teise (Eng. Separation of powers is a principle of the organization and operation of a democratic state. Lithuanian constitutional law). Vilnius: Lietuvos teisès universiteto leidybos centras, p.674. https://repository.mruni.eu/bitstream/ handle/007/15418/konstitucine_teise.pdf?sequence=1\&isAllowed=y

13. Kardelis, K. (2017). Moksliniu tyrimu metodologija ir metodai (Eng. Research methodology and methods). Mokslo ir enciklopedijų leidybos centras, p.260.

14. Kardelis, K. (2002). Modulio konspektas parengtas pagal vadoveli: Moksliniu tyrimu metodologija ir metodai. 2-asis pataisytas ir papildytas leidimas (Eng. The module summary is prepared according to the textbook: Research methodology and methods. 2nd revised and supplemented edition), p.98.

15. Kekic, L. (2007). The Economist Intelligence Units index of democracy. http://www.economist. com/media/pdf/DEMOCRACY_INDEX_2007_v3.pdf.

16. Madison, J. (1999). The Structure of the Government Must Furnish the Proper Checks and Balances Between the Different Departments. In Kesler, R. C., Rossiter, C. The Federalist Papers. New York: Hamilton, Madison, Jay.

17. Mason, J. (2002). Qualitative Interviewing: Asking, Listening and Intepreting. Qualitative Research in Action. London: Sage Publications Ltd, p. 34, p. 76. https://dx.doi.org/10.4135/9781849209656. n10.

18. May, T. (2001). Social Research: Issues, methods and process (4th edition). Berkshire: Open University Press, p.124.

19. McNabb, D. E. (2002). Research Methods in Public Administration and Nonprofit Management: Quantitative and Qualitative Approaches. Armonk; New York: M. E. Sharpe, p.19-20.

\section{Internet resources}

20. See the data available on the official website of the Central Electoral Commission of the Republic of Lithuania: http://www.vrk.lt/statiniai/puslapiai/2015_savivaldybiu_tarybu_rinkimai/output_ lt/rezultatai_daugiamand_apygardose/rezultatai_daugiamand_apygardose1turas.html.

21. See the data available on the official website of the Central Electoral Commission of the Republic of Lithuania: https://www.vrk.lt/2019-savivaldybiu tarybu/rezultatai?srcUrl=/rinkimai/864/1/1506/ rezultatai/lt/rezultataiTarNariaiMeraiSavivaldybese.html 